\title{
PENGARUH METODE CTL DAN KEMAMPUAN BERPIKIR LOGIS TERHADAP HASIL BELAJAR IPA SISWA KELAS IV SEKOLAH DASAR NEGERI 114 PALEMBANG
}

\author{
Muttia Ratna \\ Mahasiswa S2 Pendidikan Dasar Pascasarjana UNJ \\ Mutia_ratna@gmail.com
}

\begin{abstract}
This study aims to determine the effect of the CTL Method of Problem-Based Learning Technique and Problem Posing Technique and the ability to think logically to the learning outcomes of natural sciences. The study was conducted at the grade IV Elementary School 114 Palembang. The amount of students as many as 32 students. Research design using experiment method with treatment by level $2 \times 2$. Data analysis is theanalysis of variance of two lanes (ANOVA). The results of this study indicate that (1) There are differences in learning outcomes of natural science between the groups given CTL method of problem-based learning technique and the groups given CTL method of problem posing technique (2) There are interactions between CTL method and the ability to think logically to the learning outcomes of natural science.
\end{abstract}

Keywords: Problem-Based Learning Technique and Problem Posing Technique, Logical Thinking Ability, Learning outcomes.

\begin{abstract}
Abstrak: Penelitian ini bertujuan untuk mengetahui pengaruh Metode CTL Masalah Berbasis Teknik Belajar dan Problem Posing Teknik dan kemampuan untuk berpikir logis dengan hasil belajar ilmu alam. Penelitian dilakukan di kelas IV Sekolah Dasar 114 Palembang. Jumlah siswa sebanyak 32 siswa. Desain penelitian menggunakan metode eksperimen dengan pengobatan oleh tingkat $2 \times 2$. Analisis data adalah theanalysis varians dua jalur (ANOVA). Hasil penelitian ini menunjukkan bahwa (1) Ada perbedaan hasil belajar ilmu pengetahuan alam antara kelompok diberikan metode CTL teknik pembelajaran berbasis masalah dan kelompok diberikan metode CTL masalah teknik (2) berpose Ada interaksi antara metode CTL dan kemampuan untuk berpikir logis dengan hasil belajar ilmu pengetahuan alam.
\end{abstract}

Kata kunci: Problem-based learning, teknik dan problem posing teknik, logical thinking kemampuan, hasil belajar.

Pada abad ke-21 terbentuklah paradigma baru di tengah-tengah masyarakat yang lebih dikenal dengan era globalisasi, antara lain dengan terjadinya perubahan-perubahan yang serba cepat dan kompleks, baik yang menyangkut perubahan nilai maupun struktur yang berkaitan dengan kehidupan manusia. Untuk itu bangsa Indonesia perlu dibekali dengan pendidikan yang berorientasi dengan tuntutan abad ke-21. Trilling dan Fadel
(2009:48) menunjukkan 3 (tiga) struktur dan komponenyang menjadi subjek inti dari tuntutan abad ke-21 yang disebut dengan "The 21 $1^{\text {st }}$ Century Knowledge-and-Skills Rainbow" seperti pada gambar 1.1 berikut.

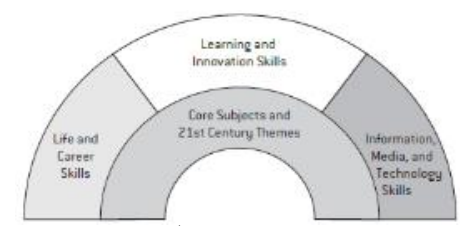

Gambar 1.1.The $21^{\text {st }}$ Century Knowledge-andSkills Rainbow 
Berdasarkan gambar 1.1 di atas dapat dikatakan bahwa subjek inti dari pembelajaran abad ke-21 dikelilingi oleh 3 (tiga) set keterampilan yang utama yakni keterampilan belajar dan inovasi; keterampilan informasi, media, dan teknologi; serta keterampilan hidup dan karir. Namun keterampilan paling utama yang harus dipenuhi di abad ke-21 adalah keterampilan belajar dan berinovasi.

Untuk memenuhi tuntutan pembelajaran abad ke-21 dan tantangan pendidikan tersebut, maka paradigma pembelajaran berbasis teaching diubah menjadi pembelajaran berbasis learning yang memberikan siswa kesempatan yang lebih besar untuk menggali pemahamannya terhadap materi yang diajarkan. Dalam pendidikan, konteks learning dikonotasikan sebagai kegiatan belajar dimana pelajar berperan aktif, bukan hanya pengajar, tetapi interaksi aktif pelajar dan pengajar memegang peran sentral dalam proses belajar. Dengan perubahan paradigma tersebut maka terjadilah pembelajaran yang bersifat learning how to learn (belajar bagaimana seharusnya belajar).

Karakteristik perubahan paradigma di atas sejalan dengan keterampilan proses. Keterampilan proses memiliki karakteristik bahwa proses pembelajaran dapat memberikan pengalaman belajar kepada siswa, sehingga mereka memiliki berbagai keterampilan. Di dalam mengaplikasikan keterampilan proses dalam kegiatan pembelajaran diharapkan siswa memiliki kemampuan secara komprehensif seperti kognitif, afektif, dan psikomotor. Untuk memenuhi hasil belajar tersebut, seorang guru dituntut untuk melaksanakan proses pembelajaran yang mampu mengembangkan keterampilan berpikir yakni proses saintifik. Proses saintifik merupakan proses pembelajaran di mana siswa melakukan kegiatan pembelajaran yakni mengamati, menanya, mengumpulkan informasi, menalar, dan mengomunikasikan gagasan. Mata pelajaran yang berelasi dengan pendekatan saintifikadalah Ilmu Pengetahuan Alam yang selanjutnya disebut IPA.

Seperti dijelaskan sebelumnya bahwa pembelajaran di abad ke-21 harus bermakna, maka begitu pula dalam pembelajaran IPA di Sekolah Dasar. Untuk membentuk pembelajaran IPA yang bermakna, maka guru harus mengetahui ciri dari kondisi pembelajaran yang bermakna. Glynn dan Duit (1995:4) menyatakan bahwa ada 5 (lima) kondisi agar pembelajaran IPA menjadi bermakna; (1) pengetahuan yang adadiaktifkan; (2) pengetahuan yang adaterkait denganpengalaman pendidikan; (3) motivasi intrinsikdikembangkan; pengetahuanbarudibangun; $\operatorname{dan}(5)$ 
Metode CTL Dan Kemampuan Berfikir Logis Mutia Ratna

pengetahuan baruditerapkan, dievaluasi, dan direvisi.

Hal senada tentang pembelajaran IPA juga dikemukakan oleh L.Moller et. al. (2009:49)

Learning is a naturally active mental and social process. When learning in natural context, human interact with their environment and manipulate the objects in that environment, observing the effects of their interventions and constructing their own interpretations of the phenomena and the results of the manipulation and sharing those interpretations with others.

Belajar adalah proses mental dan sosial yang aktif secara alami. Ketika belajar dalam konteks alam, manusia berinteraksi dengan lingkungan mereka dan memanipulasi bendabenda dilingkungan tersebut, mengamati efek dari intervensi mereka dan membangun interpretasi mereka sendiri dari fenomena dan hasil manipulasi dan berbagi interpretasi mereka dengan orang lain.

Berdasarkan hasil pengamatan awal yang dilakukan di SD Negeri 114 Kecamatan Sako Palembang khususnya di kelas IV guru memiliki kecenderungan menggunakan metode pembelajaran konvensional saat mengajar sehingga siswa cenderung pasif karena kurang dilibatkan dan hanya menerima apa yang disampaikan guru. Lebih jauh dijelaskan bahwa pembelajaran di kelas dititik beratkan pada penguasaan konsep dan target pencapaian kurikulum sehingga pembelajaran di kelas kurang meningkatkan kreativitas siswa. Padahal esensi pembelajaran IPA di kelas terletak pada prosesnya sehingga tidak bisa diajarkan dengan hanya meminta siswa menghafal konsep melainkan dengan memahami konsep berdasarkan konteks yang ada di dalam kehidupan sehari-hari dengan penyesuaian terhadap materi yang ada di dalam kurikulum. Dari hasil pengamatan juga didapatkan temuan bahwa siswa kurang termotivasi dalam pembelajaran IPA karena rendahnya minat siswa dalam belajar kelompok.

Berdasarkan hasil analisis terhadap nilai ujian akhir semester mata pelajaran IPA semester I tahun 2014/2015 siswa kelas IV E SD Negeri 114 Palembang dari jumlah siswa sebesar 24 orang, ada 15 orang $(62,5 \%)$ yang mencapai Kriteria Ketuntasan Minimal (KKM) dengan nilai rata-rata kelas sebesar 75,2 .

Berpijak pada data empiris tentang observasi proses pembelajaran di SDN 114 Palembang di atas dapat kita tarik benang merah bahwa guru merupakan aktor penting dalam skenario belajar mengajar. Guru harus mampu menyelenggarakan pendidikan dengan berorientasi pada aktivitas siswa dalam menemukan dan menetapkan makna secara mandiri sehingga proses pembelajaran akan mampu membentuk kemampuan 
berpikir tingkat tinggi pada diri siswa. Untuk itu diperlukan sebuah transformasi metode belajar yang berbasis aktivitas siswa. Salah satu metode pembelajaranyang berorientasi pada abad ke-21 adalah Metode Pembelajaran Kontekstual / Contextual Teaching and Learning (CTL).

Metode CTL merupakan metode pembelajaran yang membantu guru mengaitkan antara materi yang diajarkannya dengan situasi dunia nyata dan mendorong peserta didik membuat hubungan antara pengetahuan yang dimilikinya dan penerapannya dalam kehidupan mereka sebagai anggota keluarga dan masyarakat. Dengan penerapan metode CTL di ruang kelas, maka pembelajaran akan menjadi lebih bermakna sehingga muatan materi akan bertahan lama dalam diri siswa. Dalam aplikasinya, menurut Johnson (2007:310) ada beragam teknik yang bisa diterapkan dalam metode CTL di antaranya adalah teknik Problem Based Learning (PBL) / Pembelajaran Berbasis Masalah (PBM) dan teknik Problem Posing / Pengajuan Masalah.

Menurut Arrends yang dikutip oleh Hosnan (2014:295), Problem Based Learning (PBL) adalah teknik pembelajaran dengan pendekatan pembelajaran peserta didik pada masalah autentik sehingga peserta didik dapat menyusun pengetahuannya sendiri, menumbuh-kembangkan keterampilan yang lebih tinggi, memandirikan peserta didik dan meningkatkan kepercayaan diri sendiri. Masalah yang diangkat dari PBL merupakan masalah yang dekat dengan kehidupan peserta didik (real problem) sehingga memotivasi peserta didik untuk memikirkan jalan keluar dari masalah tersebutdan meningkatkan kemampuan berpikir tingkat tinggi dalam situasi yang berorientasi pada masalah termasuk cara bagaimana belajar.

Berbeda dengan PBL, teknik Problem Posing atau biasa disebut Pengajuan Masalah merupakan salah satu teknik pembelajaran yang awalnya dikembangkan untuk mata pelajaran Matematika namun berkembang seiring dengan kemajuan ilmu pengetahuan karena tidak hanya Matematika yang membutuhkan beragam pengajuan dan pemecahan masalah dalam penerapannya, melainkan juga ilmu-ilmu lain termasuk mata pelajaran IPA.

Pendekatan saintifik pada mata pelajaran IPA, kita akan menemukan istilah menalar. Menurut Stenberg (2012:462), penalaran adalah proses berpikir yang logis dan sistematis atas fakta-fakta empiris yang dapat diamati untuk memperoleh simpulan berupa pengetahuan. Selama mentransfer peristiwaperistiwa khusus ke otak, pengalaman tersimpan di memori otak kemudian berelasi dan berinteraksi dengan pengalaman sebelumnya yang sudah tersedia. Menalar erat 
Metode CTL Dan Kemampuan Berfikir Logis

Mutia Ratna

kaitannya dengan proses berpikir logis pada peserta didik dimana dalam berpikir logis mereka dilatih untuk menarik sebuah kesimpulan dari sebuah fakta yang belum terdefinisi. Untuk itu penanaman kemampuan berpikir logis tepat bila diterapkan dalam pendekatan saintifik karena peserta didik dianjurkan untuk tidak menerima begitu saja sebuah konsep, melainkan juga harus menghubungkan fakta-fakta yang terjadi sehingga mampu mengonstruksikan fakta serta mendapatkan pengetahuan dan kesimpulan yang tepat.

\section{METODE}

Metode yang digunakan dalam penelitian ini adalah metode eksperimen dengan rancangan desain Treatment by level 2 x 2 . Metode eksperimen dapat diartikan sebagai metode penelitian yang digunakan untuk mencari pengaruh perlakuan tertentu terhadap yang lain dalam kondisi yang terkendalikan. Metode eksperimen dengan variabel terikat adalah hasil belajar IPA (Y). Penelitian ini dilakukan perlakuan (treatment) untuk mencari pengaruh di antara dua variabel yaitu variabel perlakuan adalah metode pembelajaran $\left(\mathrm{X}_{1}\right)$ dan variabel moderator adalah kemampuan berpikir logis $\left(\mathrm{X}_{2}\right)$. Variabel perlakuan adalah metode CTL yang terdiri atas dua teknik yaitu teknik Problem Based Learning dan Problem Posing $\left(\mathrm{X}_{1}\right)$. Variabel moderator adalah kemampuan berpikir logis ada dua yaitu kemampuan berpikir logis tinggi dan kemampuan berpikir logis rendah $\left(\mathrm{X}_{2}\right)$.

Percobaan dilakukan pada dua kelompok siswa yakni kelompok berpikir logis tinggi dan kelompok berpikir logis rendah mendapat perlakuan dengan pemberian metode CTL teknik Problem Based Learning dan kelompok berpikir logis tinggi dan kelompok berpikir logis rendah mendapat perlakuan dengan pemberian metode CTL teknik Problem Posing. Adapun rancangan dalam penelitian ini terlihat pada Tabel 1 sebagai berikut.

\begin{tabular}{|c|c|c|}
\hline Metode CTL (A) & $\begin{array}{c}\text { Metode } \\
\text { CTL }\end{array}$ & $\begin{array}{c}\text { Metode } \\
\text { CTL }\end{array}$ \\
\hline KemampuanBerpikir & Teknik & Teknik \\
\hline Logis (B) & $\begin{array}{c}\text { Problem } \\
\text { Based } \\
\text { Learning } \\
\left(\mathrm{A}_{1}\right)\end{array}$ & $\begin{array}{c}\text { Problem } \\
\text { Posing } \\
\text { (A2) }\end{array}$ \\
\hline Tinggi $\left(B_{1}\right)$ & $\mathbf{A}_{1} \mathbf{B}_{1}$ & $\mathbf{A}_{2} \mathbf{B}_{1}$ \\
\hline Rendah (B $\left.\mathbf{B}_{2}\right)$ & $\mathbf{A}_{1} \mathbf{B}_{2}$ & $\mathbf{A}_{2} \mathbf{B}_{2}$ \\
\hline
\end{tabular}

Tabel 1. Rancangan Treatment by level

$2 \times 2$

Oliver (2013:128) mengemukakan pengertian sampel secara sederhana sebagai bagian dari seluruh jumlah populasi yang diambil dari populasi dengan cara sedemikian rupa sehingga dapat dianggap mewakili seluruh anggota populasi. Teknik penarikan sampel dalam penelitian ini menggunakan cluster simple random sampling yakni cara pengambilan sampel dari anggota populasi 
dengan cara acak tanpa memperhatikan strata 9tingkatan) dalam anggota populasi tersebut.

Selanjutnya pada tes kemampuan berpikir logis ditentukan kelompok atas dan kelompok bawah. Siswa dikategorikan ke dalam kelompok berpikir logis tinggi apabila skor berada pada rentang $27 \%$ skor tertinggi. Kemudian siswa dikategorikan ke dalam kelompok berpikir logis rendah apabila skor berada pada rentang $27 \%$ skor terendah. Maka didapatkan $27 \%$ x $32=8$ sampel untuk setiap kelompok.

\section{HASIL}

Perbedaan hasil belajar IPA antara kelompok yang diberikan metode CTL teknik Problem Based Learning dan kelompok yang diberikan metode CTL teknik Problem Posing

Berdasarkan hasil analisis varians (ANAVA) pada taraf signifikan $\alpha=0,05$, didapat $F_{\text {hitung }}=4,93>F_{\text {tabel }}=4,15$. Dengan demikian $\mathrm{F}_{\mathrm{o}}>\mathrm{F}_{\mathrm{t}}$, sehingga $\mathrm{H}_{0}$ ditolak, sehingga dapat disimpulkan bahwa secara keseluruhan terdapat perbedaan pengaruh yang signifikan antara kelompok siswa yang diberikan metode CTL Teknik Problem Based Learning dengan kelompok siswa yang diberikan metode CTL Teknik Problem Posing terhadap hasil belajar IPA. Oleh karena itu, hasil belajar IPA yang diberikan metode CTL teknik Problem Based Learning ( $\bar{X}=81$ dan $\mathrm{s}=8,453)$ lebih baik secara nyata dibandingkan dengan yang diberikan metode CTL teknik Problem Posing $(\bar{X}=75$ dan s $=$ 7,659).

\section{Interaksi Metode CTL dan Kemampuan Berpikir Logis terhadap Hasil Belajar IPA (INT A X B)}

Hasil perhitungan ANAVA dapat diketahui bahwa nilai hasil pengujian hipotesis kedua yang disajikan dalam tabel ANAVA pada baris interaksi A $X$ B menunjukkan bahwa $\mathrm{H}_{0}$ ditolak berdasarkan nilai $\mathrm{F}_{\text {hitung }}=6,89>\mathrm{F}_{\text {tabel }}(0,05)=4,15$ dengan demikian dapat diambil keputusan bahwa terdapat pengaruh interaksi yang signifikan antara metode CTL dan kemampuan berpikir logis terhadap hasil belajar IPA.

Data hasil penelitian, diperoleh skor ratarata hasil belajar IPA antara kelompok siswa yang memiliki kemampuan berpikir logis tinggi yang diberikan metode CTL teknik Problem Based Learning adalah sebesar 87 dan kelompok siswa yang memiliki kemampuan berpikir logis rendah yang diberikan metode CTL teknik Problem Posing Learning adalah sebesar 74,5. Untuk skor rata-rata hasil belajar IPA antara kelompok siswa yang memiliki kemampuan berpikir logis tinggi yang tinggi yang diberikan metode CTL teknik Problem Based Learning adalah sebesar 75 dan kelompok siswa yang memiliki kemampuan berpikir 
logis rendah yang diberikan metode CTL teknik Problem Posing adalah sebesar 75,5.

2. Pada kelompok siswa yang memiliki kemampuan berpikir logis tinggi, terdapa perbedaan Hasil Belajar IPA Kelompok siswa yang belajar dengan Metode CTL Teknik Problem Based Learning dengan Kelompok Siswa yang Belajar dengan Metode CTL Teknik Problem Posing.

Perhitungan analisis varians tahap lanjut dengan Uji Tukey adalah untuk membandingkan kelompok yang memiliki kemampuan berpikir logis tinggi yang diberikan metode CTL teknik Problem Based Learning dan yang diberikan metode CTL teknik Probem Posing. Perhitungan Uji Tukey $\mathrm{A}_{1} \mathrm{~B}_{1}>\mathrm{A}_{2} \mathrm{~B}_{1}=$ Qhitung $=10,10>$ $\mathrm{Q}_{\text {tabel0,05:4:8 }}=$ 4,07 atau Qhitung $>$ Qtabel pada taraf signifikan $\alpha=0,05$, dengan demikian $\mathrm{H} 0$ ditolak dan hipotesis alternatif diterima. Sehingga dapat ditafsirkan hasil belajar IPA antara kelompok siswa yang diberikan metode CTL teknik Problem Based Learning lebih tinggi dibandingkan dengan kelompok siswa yang diberikan metode CTL teknik Problem Posing.

Oleh karena itu, bagi siswa yang memiliki kemampuan berpikir logis tinggi yang diberikan metode CTL Teknik Problem Based Learning ( $\bar{X}=87$ dan s $=5,952$ ) lebih tinggi secara nyata dibandingkan yang diberikan metode CTL teknik Problem Posing $(\bar{X}=74,5$ dan $\mathrm{s}=7,690)$.

3. Pada kelompok yang memiliki kemampuan berpikir logis rendah, terdapat perbedaan hasil belajar IPA antara kelompok siswa yang diberikan metode CTL teknik Problem Based Learning dan kelompok siswa yang diberikan metode CTL teknik Problem Posing ( $\left.\mathrm{A}_{1} \mathrm{~B}_{2} \& \mathrm{~A}_{2} \mathrm{~B}_{2}\right)$

Perhitungan analisis varians tahap lanjut dengan Uji Tukey adalah untuk membandingkan kelompok yang memiliki kemampuan berpikir logis rendah yang diberikan metode CTL teknik Problem Based Learning dan yang diberikan metode CTL teknik Problem Posing. Perhitungan Uji Tukey $\mathrm{A}_{1} \mathrm{~B}_{2}<\mathrm{A}_{2} \mathrm{~B}_{2}=Q_{\text {hitung }}=-0,40$ lebih kecil daripada $Q_{\text {tabel0,05:4:8 }}=4,07$ atau $Q_{\text {hitung }}<$ $Q_{\text {tabel }}$ pada taraf signifikan $\alpha=0,05$, dengan demikian $\mathrm{H} 0$ ditolak dan hipotesis alternatif diterima. Sehingga dapat ditafsirkan hasil belajar IPA antara kelompok siswa yang diberikan metode CTL teknik Problem Based Learning lebih rendah dibandingkan dengan kelompok siswa yang dibeirkan metode CTL teknik Problem Posing.

Oleh karena itu, bagi siswa yang memiliki kemampuan berpikir logis rendah yang diberikan metode CTL teknik Problem Based Learning ( $\bar{X}=75$ dan $\mathrm{s}=5,952)$ lebih rendah secara nyata dibandingkan yang 
diberikan metode CTL teknik Problem Posing $(\bar{X}=75,5$ dan $\mathrm{s}=8,124)$.

\section{PEMBAHASAN}

\section{Perbedaan hasil belajar IPA antara kelompok yang diberikan metode CTL Teknik Problem Based Learning dan kelompok yang diberikan metode CTL Teknik Problem Posing}

Hasil penelitian diperkuat dengan pendapat Arrends (2012:396) yang mengatakan bahwa siswa belajar mengonstruksi pengetahuannya melalui interaksi dengan lingkungannya. Teknik PBL dapat membuat siswa belajar melalui upaya penyelesaian dunia nyata secara terstruktur untuk mengonstruksi pengetahuan siswa. Pembelajaran ini menuntut siswa untuk aktif melakukan penyelidikan dalam menyelesaikan permasalahan dan guru berperan sebagai fasilitator atau pembimbing. Pembelajaran akan dapat membentuk kemampuan berpikir tingkat tinggi (higher order thinking skills) dan meningkatkan kemampuan siswa untuk berpikir kritis.

Dengan berlandaskan objek yang sama dengan PBL, yaitu sebuah masalah atau persoalan, Brown dan Walter (2004:12) mendefinisikan teknik Problem Posing sebagai teknik pembelajaran yang dapat digunakan untuk mengembangkan kecakapan berpikir siswa karena dalam pembelajaran ini, siswa dikondisikan untuk menggali informasi sebanyak-banyaknya dari berbagai literatur, merumuskan soal atau pertanyaan dari situasi yang ada, menentukan jawaban atau pemecahan dari permasalahan yang mereka buat serta mencari alternatif pemecahannya secara mandiri. Hal ini berarti hipotesis penelitian secara keseluruhan adalah terdapat perbedaan hasil belajar IPA yang diberikan metode CTL teknik Problem Based Learning dengan yang diberikan metode CTL teknik Problem Posing.

\section{Interaksi Metode CTL dan Kemampuan Berpikir Logis terhadap Hasil Belajar IPA (INT A X B)}

Teknik Problem Based Learning (PBL) mengemuka karena adanya keprihatinan para praktisi akan rendahnya kemampuan praktis para calon dokter yang cerdas secara akademik. Artinya mereka mampu menguraikan sebuah ilmu dalam bentuk teori tetapi tidak mampu mempraktekkannya dalam kehidupan nyata. Untuk itu PBL dikembangkan menjadi sebuah teknik yang mampu mengasah keterampilan siswa dalam mengkaji dan memecahkan masalah kontekstual dengan menggunakan berbagai disiplin ilmu. Arrends

(2012:398) menjabarkan 3 (tiga) hasil belajar (outcome) dari teknik PBLberupa (1) keterampilan penyelidikan dan mengatasi masalah; (2) perilaku dan keterampilan sosial sesuai peran 
Metode CTL Dan Kemampuan Berfikir Logis

Mutia Ratna

orang dewasa; dan (3) keterampilan untuk belajar secara mandiri. Dari outcome tersebut dapat dipastikan bahwa teknik ini mampu mengembangkan keterampilan berpikir siswa ke tahap yang lebih tinggi (higher order thinking skills).

Trianto (2007:67-68) menjelaskan teknik Problem Posing dengan istilah pengkonstruksian masalah. Dalam teknik ini, siswa mengajukan masalah atau soal yang didasarkan pada situasi yang diberikan oleh guru. Situasi dalam hal ini bisa berupa informasi (pernyataan), pertanyaan dan sebagainya. Tentunya saat mengonstruksi masalah atau pertanyaan, siswa melakukan kegiatan berpikir dengan berlandaskan situasi yang dirancang oleh guru.

Dalam kedua teknik yang telah dipaparkan di atas, siswa memerlukan kemampuan berpikir yang mengarah pada kesimpulan yang benar. Semakin baik proses berpikir yang dilakukan, maka seseorang dapat menentukan dengan jelas tindakan apa yang harus dilakukan. Proses berpikir yang menghasilkan kesimpulan yang benar disebut dengan berpikir logis. Di dalam berpikir logis, terdapat 3 (tiga) komponen yang harus ada meliputi (1) pengertian (concept), (2)

keputusan (decision), (3) penalaran (reasoning). Ketiga komponen dalam berpikir logis tersebut bisa diwujudkan melalui dua cara yakni melalui teknik deduktif dan induktif. Keduanya merupakan teknik bernalar yang sama-sama menghasilkan keputusan. Hal ini berarti hipotesis penelitian terdapat interaksi antara metode CTL dengan kemampuan berpikir logis terhadap hasil belajar IPA.

\section{Pada kelompok siswa yang memiliki} kemampuan berpikir logis tinggi, terdapa perbedaan Hasil Belajar IPA Kelompok siswa yang belajar dengan Metode CTL Teknik Problem Based Learning dengan Kelompok Siswa yang Belajar dengan Metode CTL Teknik Problem Posing.

Hasil penelitian didukung dengan adanya pendapat Langen dan Welsh (2006)yang menjelaskan bahwa teknik Problem Based Learning memusatkan perhatian pada masalah yang terjadi dan dekat dengan kehidupan sehari-hari siswa. Kebermaknaan belajar merupakan ciri dari teknik pembelajaran ini. Karena siswa dituntut untuk berpikir ilmiah dengan cara bernalar dan memikirkan pemecahan dari setiap permasalahan melalui penguraian pilihan-pilihan pemecahan masalah, sehingga dihasilkan sebuah kesimpulan yang benar.

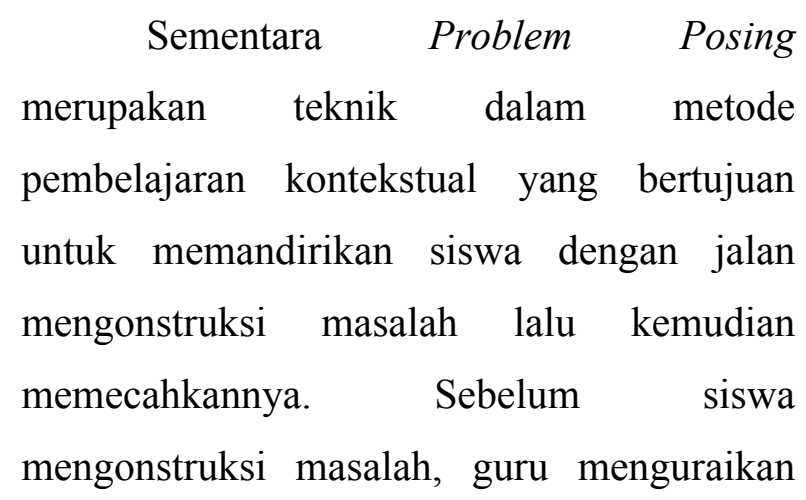


terlebih dahulu pertanyaan atau pernyataan yang dapat dijadikan bahan bagi siswa untuk membuat suatu pertanyaan kembali. Dari pernyataan di atas, dapat digaris bawahi bahwa siswa masih diberikan bimbingan dari guru untuk mengonstruk sebuah masalah dan permasalahan yang diajukan guru bisa jadi tidak sesuai dengan konteks permasalahan yang dekat dengan kehidupan siswa.

4. Pada kelompok yang memiliki kemampuan berpikir logis rendah, terdapat perbedaan hasil belajar IPA antara kelompok siswa yang diberikan metode CTL teknik Problem Based Learning dan kelompok siswa yang diberikan metode CTL teknik Problem Posing $\left(\mathrm{A}_{1} \mathrm{~B}_{2} \& \mathrm{~A}_{2} \mathrm{~B}_{2}\right)$

Teknik Problem Based Learning yang dikembangkan oleh Arrends (2012:396) mendefinisikan PBL sebagai suatu teknik pembelajaran yang berpusat pada siswa (student-centered), mengorganisasikan kurikulum dengan pembelajaran kontekstual dalam situasi dan masalah nyata sehari-hari. Kwan \& Somenjelaskan dalam studi ilmiahnya bahwa pembelajaran dengan teknik ini membuat siswa menjadi lebih aktif, terintegrasi antar disiplin ilmu, dan berhubungan satu dengan yang lain tanpa terpecah-pecah. Siswa dapat bekerja sama dalam kelompok berdiskusi dengan tanggung jawab untuk belajar bersama dalam prosesnya dapat membangun kemampuan berpikir dan keterampilan memecahkan masalah serta keterampilan untuk berkolaborasi bagi siswa. Karena siswa dituntut untuk berpikir ilmiah dengan cara bernalar dan memikirkan pemecahan dari setiap permasalahan melalui penguraian pilihan-pilihan pemecahan masalah, sehingga dihasilkan sebuah kesimpulan yang benar. Kesimpulan yang didapat dari sebuah pemikiran dan pengamatan akan menghasilkan sebuah fakta atau data baru yang bisa dipertanggung jawabkan kebenarannya.

Sementara Problem Posing merupakan teknik dalam metode pembelajaran kontekstual yang bertujuan untuk memandirikan siswa dengan jalan mengonstruksi masalah lalu kemudian memecahkannya. Dengan adanya peran guru sebagai main role, siswa mengonstruksi pertanyaan melalui pernyataan dan pertanyaan yang diajukan guru terlebih dahuiu.

Kemampuan menalar memang datang dari sebuah permasalahan atau data yang sudah diketahui, namun ada baiknya jika data atau permasalahan tersebut datang secara kontekstual bukan dengan bimbingan guru. Sehingga proses pemikiran atau bernalar tidak sengaja diarahkan menuju kebenaran atau kesimpulan yang sesungguhnya.

\section{SIMPULAN}

Penelitian ini menggunakan metode eksperimen yang melibatkan variabel bebas, 
yaitu metode CTL teknik Problem Based Learning dan metode CTL teknik Problem Posing dan kemampuan berpikir logis, sedangkan sebagai variabel terikatnya adalah hasil belajar IPA siswa kelas IV SD Negeri 114 Palembang.

Berdasarkan hasil analisis data, hasil pengujian hipotesis dan hasil pembahasan penelitian yang telah diperoleh dijelaskan beberapa kesimpulan sebagai berikut:

1. Metode CTL teknik Problem Based Learning memiliki pengaruh yang lebih tinggi nilainya dari metode CTL teknik Problem Posing terhadap hasil belajar IPA.

2. Terdapat interaksi antara metode CTL teknik Problem Based Learning dan metode CTL teknik Problem Posing dan kemampuan berpikir logis terhadap hasil belajar IPA.

3. Metode CTL teknik Problem Based Learning lebih tinggi nilainya dari metode CTL teknik Problem Posing pada kelompok siswa yang memiliki kemampuan berpikir logis tinggi terhadap hasil belajar IPA.

4. Metode CTL teknik Problem Based Learning lebih rendah nilainya dari metode CTL teknik Problem Posing pada kelompok siswa yang memiliki kemampuan berpikir logis rendah terhadap hasil belajar IPA.

\section{DAFTAR PUSTAKA}

Arends, R. I \& Ann Klicher. 2010. Teaching for Student Learning: Becoming an Accomplished Teacher. New York: Routledge.

Brown, Stephen I \& Marrion I. Walter. 2004. The Art of Problem Posing: Third Edition. New York: Routledge.

Glynn, Shawn M \& Reinders Duit, 1995. Learning Science in The Schools. USA: Lawrence.

Hosnan. 2014. Pendekatan Saintifik dan Kontekstual dalam Pembelajaran Abad 21. Jakarta: Ghalia Indonesia.

Moller, Leslie, Jason Bond Huett, \& Douglas M. Harvey. 2014. Learning and Instructional Technologies for The $21^{\text {st }}$ Century. New York: Springer ScienceBusiness Mediarn LLC.

Oliver, Paul. 2013. Writing Your Thesis. Sage Publications Ltd

Setiawan, Ibnu. 2007. Contextual Teaching \& Learning: Menjadikan Kegiatan Belajar-Mengajar dan Bermakna. Bandung: MLC.

Stenberg, Robert \& Karin Stenberg, 2002. Cognition. Canada: Wadswoth Cengage Learning.

Tan, Oon Seng. 2003. Problem Based Learning Innovation: Using Problem to Power Learning in The $21^{\text {st }}$ Century. Singapore: Thomson Learning.

Trianto. 2007. Model-Model Pembelajaran Inovatif Berorientasi Konstruktif. Jakarta: Prestasi Pustaka Publisher.

Trilling, Bernie \& Charles Fadel. 2009. $21^{\text {st }}$ Century Skills: Learning for Life in Our Times. San Fransisco: Jossey Bass. 
JURNAL PENDIDIKAN DASAR

Volume 6 Edisi 2 Desember 2015

Langen, Tom A. \& Rick Welsh, 2006.

"Effects of PBL Approach on Attitude Change and Science and Policy Content Knowledge." Conservation Biology Vol.20 No. 3:600-608, (dikutip darihttp://m.ebscohost.com) diakses tanggal 23 Februari 2015.

Kwan, Tammy \& Max So, International Research Group, (dikutip dari http://m.ebscohost.com) diakses tanggal 23 Februari 2015. 